\title{
STEM CELL THERAPY IN COMMUNICATION DISORDERS
}

\author{
Nahla Abd el-Aziz Rifaie ${ }^{1}$, Dina Ahmed Elsayed ${ }^{1}$ and Elham Magdy Hafiz ${ }^{2}$, Nermeen Atef \\ Elhusseiny ${ }^{2}$ \\ ${ }^{1}$ Phoniatrics Unit, ENT-Department, Faculty of Medicine, Ain-Shams University, Egypt. \\ ${ }^{2}$ Phoniatrics Unit, ENT Department, Faculty of Medicine, Zagazig University, Egypt.
}

Corresponding author:

Nermeen Atef Elhusseiny, Phoniatrics Unit - ENT Department, Faculty of Medicine, Zagazig University.

Email:

nermeenatefphoniatric@yahoo.com,

\section{INTRODUCTION}

tem cells are un-differentiated cells that
can proliferate into specialized cells and
can divide to produce more stem cells. There are
five main types of stem cells: embryonic stem
cells, from the inner cell mass of blastocysts, adult
stem cells, from various tissues, fetal stem cells
that arise from different fetal tissues, induced
pluripotent stem cells (iPSCs) that are
produced by modification of adult stem cells
by reprogramming to increase its potency and
produce induced pluripotent stem cells
(iPSCs). The last type is amniotic stem cells
that are extracted from the amniotic fluid.
Stem cells act as a repair system for the body,
replenishing adult tissues ${ }^{(I)}$.
The two main properties of stem cells are
self-renewal and potency:
1-Self -renewal: means that stem cells can
enter different cycles of cell division with
preservation of its undifferentiated state by
Obligatory asymmetric replication.

Stem cells are un-differentiated cells that can proliferate into specialized cells and can divide to produce more stem cells. There are stem cells, from various tissues, fetal stem cells that arise from different fetal tissues, induced pluripotent stem cells (iPSCs) that are produced by modification of adult stem cells by reprogramming to increase its potency and produce induced pluripotent stem cells (iPSCs). The last type is amniotic stem cells that are extracted from the amniotic fluid. Stem cells act as a repair system for the body, replenishing adult tissues ${ }^{(1)}$

The two main properties of stem cells are self-renewal and potency:

enter different cycles of cell division with Obligatory asymmetric replication.
\end{abstract}

Background: Stem cell therapy is considered as a golden type of therapy that can help us in the future to solve many problems that we suffer from them. We can use stem cell in treating many communication disorders as in autism and in vocal fold regeneration after atrophy and scar.

Subjects and methods: We collected studies done on using stem cell in autism and vocal fold regeneration in the last 15 years in from 1-2002 until 3-2017 in Pub-med and emedicine

Results: We extracted the information from the studies and the results were discussed to know stem cell effectiveness and safety.

Conclusion: Stem cell therapy is effective in treating many symptoms of autism and improve histology and morphology of vocal fold after atrophy and scar of vocal fold also, stem cell therapy is safe.

Key words: stem cell- therapy -role-treatment-autism-vocal fold regeneration.
2-Potency: means the capacity for differentiation into specialized cell types ${ }^{(2)}$.

Stem cell therapy is considered as one of the most important lines of therapy in the future in different branches of medicine as liver cirrhosis chronic limb ischemia, end stage heart failure and different neurological disorders $^{(3)}$

Our study include the role of stem cell in different communication disorders as in autism and regeneration of vocal fold after vocal fold scar, atrophy or sulcus vocalis .

In autism, Stem cells act by five mechanisms. The first one is angiogenesis that aims to increase local blood supply to the damaged areas by formation of new collateral blood vessels and differentiation of stem cells into endothelial cells. This leads to decrease hypoxia and damaged neural tissue ${ }^{(4)}$. The second mechanism is immuno-regulation that occurs by inhibition of $\mathrm{T}$ cells, $\mathrm{B}$ cells, and natural killer (NK) cells, increased activity of dendritic cells, inhibition of $\mathrm{T}$ lymphocyte 
pro-inflammatory cytokine production and regulation of anti-inflammatory $\mathrm{IL}-10$ and TGF-beta. This leads to decrease in the damage with improvement of function .This anti-inflammatory effect helps in treatment of the intestinal inflammatory problems that commonly occur with autism ${ }^{[5]}$. The third one is the paracrine action of stem cells as stem cells have the ability to secrete many of trophic factors as ciliary neurotrophic factor (CNTF), vascular endothelial growth factor (VEGF) and fibroblast growth factor. All these factors help in more repair in structure, function and maturation of natural endogenous stem cells that present normally in the body. The fourth mechanism is that stem cells have extraordinary characteristics by their strong immunosuppressive activity so no need for immunosuppressive drugs and no fear of graft-versus reaction .The last mechanism is the ability to produce excess trophic and growth factors ${ }^{(5)}$.

Stem cell injection in autistic children leads to improvement of sociality by increasing attention, concentration, memory, eye contact, social smile, increase the ability to take turns in conservation, initiate conservation by himself, decrease the repetitive movements of children, improve the language of the children, decrease the echolalia and improve pragmatics ${ }^{(6)}$

In addition to the previous, stem cells injection can lead to increase the levels of growth factors in the brain, improvement of appetite and immunity of children, decrease the intestinal manifestations, improvement of aggressive behaviors and self-injurious behaviors and insisting on their opinion, improvement of sensation, improvement of glucose metabolism in brain, decreased apoptosis and improvement in different scales of autism as CARS( childhood autism rating scale),CGI(clinical global imprecision scale) , ABC (autism behavior checklist) ${ }^{(6)}$.

Regeneration of vocal fold atrophy occurs by injection of stem cells directly in the vocal folds. This enhances regeneration, reduction in scar tissue and fibrosis, deposition of type I collagen, improvement of vocal fold viscoelastic properties ,stimulating wound healing and restoring the anatomical and physiological structure of $\mathrm{VF}^{(7)}$. Different stem cells play a role in regeneration of vocal folds by different mechanisms. Bone marrow derived mesenchmal stem cells can enhance reepithalization and formation of new blood vessels and increase the level of hyaluronic acid synthesis. Stem cells can differentiate into different types of cells as epithelium, muscles so all of that help in regeneration of vocal fold. Bone marrow mesenchymal stem cells can remain in the tissues for 8 weeks ${ }^{(8)}$. Adipose derived mesenchymal stem cells have the same capacity for proliferation and differentiation as bone marrow derived mesenchymal stem cells and also the production of growth factors so they produce good results in regeneration of vocal folds. Adipose derived mesenchymal stem cells can remain in the tissues for 6 months ${ }^{(9)}$. Embryonic stem cells, in spite of their higher ability for proliferation and differentiation into different types of cells and its capacity to regain the elasticity and normal movement of vocal fold mucosa, there is restriction in its use due to ethical issues and possibility of tumor formation ${ }^{(10)}$.

\section{SUBJECTS \& METHODS}

Search strategy: The information was collected from studies that were done in the last 15 years from 1-2002 up to 3-2017 from different sources as different web sites as: pub-Med, eMedicine and then we excluded the duplicated and unrelated studies.

The results were discussed to know the stem cells effectiveness in treating autism and vocal fold regeneration.

Search terms for electronic Databases: The following terms were used as (stem cell- role -treatment-autism- regeneration of vocal folds).

Inclusion criteria: We collected studies that used stem cell therapy in treatment of autism and vocal fold regeneration. We selected studies written in English. The studies used different types of stem cells with different modes of administrations in therapy .The patients are either in early or late stages of disease on humans and animals.

Exclusion criteria: Presence of other comorbidity as renal failure or liver failure and infectious diseases as hepatitis or pregnancy in patients under the study. Letters, articles, unpublished manuscripts, government reports, 
books and book chapters, conference proceedings, meeting abstracts, lectures, reviews, studies of other language than English and duplicated articles.

Level of evidence of studies: The selected studies are evaluated by evidence-based medicine criteria by the use of the classification of the U.S. Preventive Services Task Force and UK National Health Service Protocol.

\section{U.S. Preventive Services Task Force:}

Level I: For properly designed randomized controlled trail.
Level II-1: For controlled trails without randomization.

Level II-2: Well-designed cohort or case control analytic studies from more than one center or research group.

Level II-3: For uncontrolled studies and multiple time series with or without intervention.

Level III: For opinions of respected authors depending on clinical experience, descriptive studies

Level of evidence of autism studies:

\begin{tabular}{|c|c|c|}
\hline Authors & Study design & Level of evidence \\
\hline Sharma et al. $(2013)^{(11)}$ & Open- Label, Uncontrolled study & II-3 \\
\hline Tao et al. $(2013)^{(12)}$ & $\begin{array}{l}\text { Non randomized Open- Label } \\
\text { (unblinded), controlled study }\end{array}$ & II-1 \\
\hline Bradstreetet al. (2014) ${ }^{(13)}$ & Uncontrolled blinded study & II-3 \\
\hline Segal-Gavish et al. $(2015)^{(14)}$ & Randomized Controlled Study & I \\
\hline Ha et al. $(2016)^{(15)}$ & Non randomized Controlled Study & II-1 \\
\hline Perets et al. $(2017)^{(16)}$ & Randomized Controlled Study & I \\
\hline
\end{tabular}

Level of evidence of regeneration of vocal fold studies

\begin{tabular}{|c|c|c|}
\hline Authors & Type of study & Level of evidence \\
\hline Hertegard et al. (2006) $)^{(17)}$ & Non randomized controlled study & II-1 \\
\hline Svensson et al. $(2010)^{(18)}$ & Non randomized controlled study & II-1 \\
\hline Hong et al. (2011) $)^{(19)}$ & Randomized controlled study & I \\
\hline Peng et al. (2013) & Non Randomized controlled study & II-1 \\
\hline Mo Kim et al.(2014) & Randomized controlled study & I \\
\hline Hu et al. (2014) & Non Randomized controlled study & II-1 \\
\hline Valerie et al. $(2015)^{(23)}$ & Non Randomized Controlled study & II-1 \\
\hline
\end{tabular}




\section{1-Results of autism:}

\section{RESULTS}

661 studies were identified by pub-med and e-medicine then after excluding the duplicate studies and the unrelated studies, the number became 22 studies, then we excluded 16 papers as they are reviews without clinical trials or results, so the end result is 6 studies

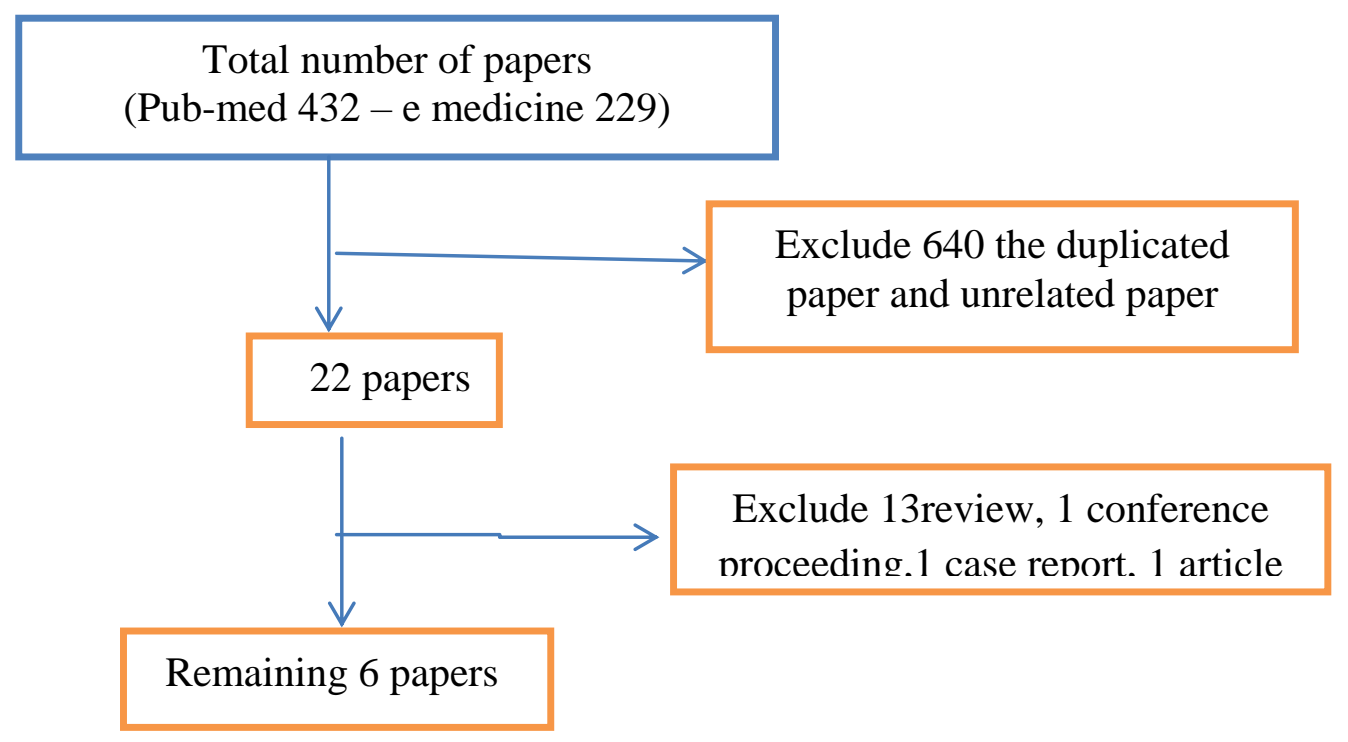

Figure1: Flow chart of autism results

\section{2-Results of regeneration of vocal fold:}

65 studies were identified by Pub-med, e-medicine, then after excluding the duplicate studies and the unrelated studies, the number became 9 studies ,then we excluded 2 studies ( 1 systematic review -1 the study use other type of cells (small intestinal sub mucosa) beside stem cell therapy) ,so the result is 7 studies.

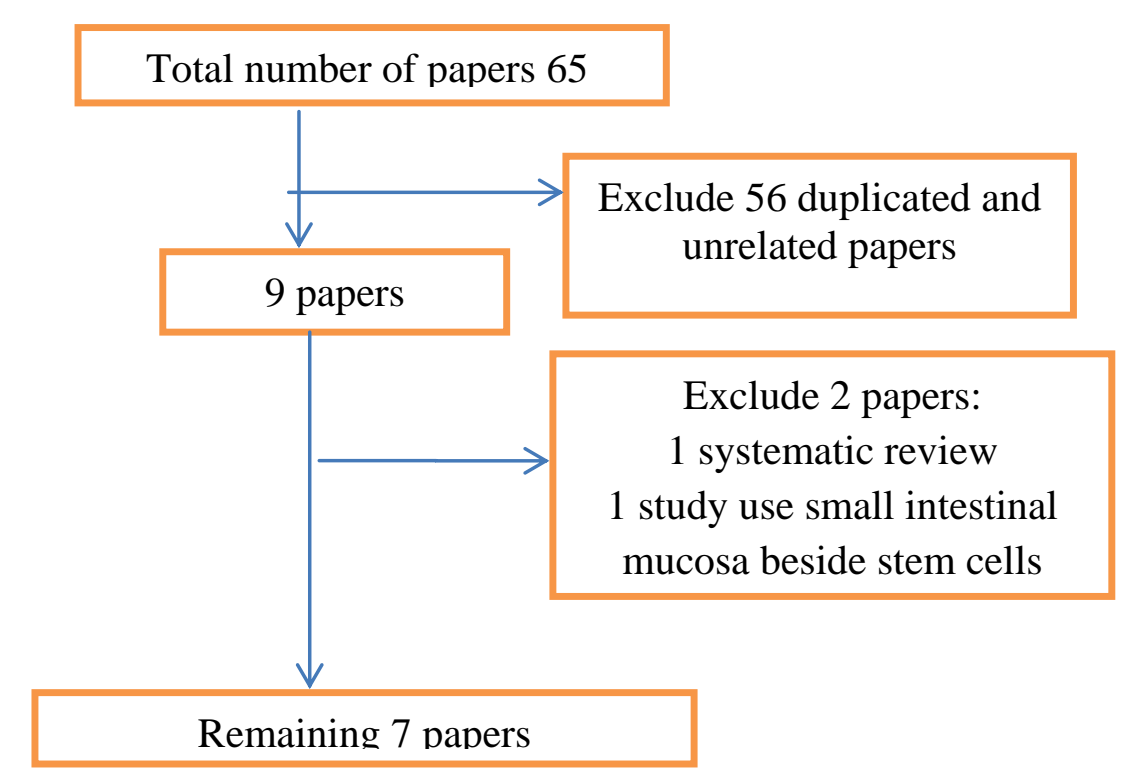

Figure 2: Flow chart of regeneration of vocal fold studies 


\section{1 - Autsin}

Table 1-1: Results of autism.

\begin{tabular}{|c|c|c|c|c|c|}
\hline Authors & Subjects & Type of cells & $\begin{array}{c}\text { Dose of stem } \\
\text { cells }\end{array}$ & $\begin{array}{l}\text { Mode of } \\
\text { transmission }\end{array}$ & Results of therapy \\
\hline Sharma et al. $(2013)^{(5)}$ & 32 patients with autism & $\begin{array}{l}\text { Autologus } \\
\text { bone marrow } \\
\text { mononuclear } \\
\text { cells }\end{array}$ & $\begin{array}{l}8.19 \times 10^{7} \\
\text { autologus } \\
\text { bone marrow } \\
\text { mononuclear } \\
\text { cells }\end{array}$ & $\begin{array}{l}\text { Intrathecal } \\
\text { injection } \\
\text { between } \\
\text { fourth and } \\
\text { fifth lumbar } \\
\text { vertebra }\end{array}$ & $\begin{array}{l}\text { 1-91\% of patient improved in } \\
\text { ISAA scale. } \\
2-62 \% \text { of the patients } \\
\text { improved in CGI scale. } \\
3-96 \% \text { of patients show } \\
\text { global improvement. } \\
\text { 4- Few side effects treated by } \\
\text { medical treatment. } \\
\text { 5- PET-CT scan show: } \\
\text { Improvement of metabolism } \\
\text { with proper oxygenation. }\end{array}$ \\
\hline Tao et al. $(2013)^{(6)}$ & $\begin{array}{l}37 \text { autistic patients divided } \\
\text { into } 3 \text { groups: } \\
\text { a- CBMNC group: took } \\
\text { (CBMNC-rehabilitation) } \\
\text { b- Combination group: } \\
\text { took (CBMNC-UCMSC- } \\
\text { rehabilation) } \\
\text { c- Control group } \\
\text { (Rehabilatation). }\end{array}$ & $\begin{array}{l}\text { Human cord } \\
\text { blood } \\
\text { mononuclear } \\
\text { cells } \\
\text { (CBMNC) } \\
\text { and umblical } \\
\text { cord derived } \\
\text { mesenchymal } \\
\text { stem cells } \\
\text { (UCMSC) }\end{array}$ & $\begin{array}{l}4 \\
\text { transplantations } \\
\text { with } 5-7 \text { days } \\
\text { interval : } \\
\text {-CBMNC } \\
\text { dose: } 2 \times 10^{6} / \mathrm{kg} \\
\text {-UCMSC } \\
\text { dose: } 1 \times 10^{6} \\
\text { /kg }\end{array}$ & $\begin{array}{l}\text { The first dose } \\
\text { is intravenous } \\
\text { and the other } \\
\text { three are } \\
\text { intratheccal }\end{array}$ & $\begin{array}{l}\text { 1-No side effects occur. } \\
\text { 2-There is improvement in } \\
\text { behavior, CARS results and } \\
\text { general condition in cell } \\
\text { grafted groups, but the best } \\
\text { improvement in combination } \\
\text { group. }\end{array}$ \\
\hline
\end{tabular}

PET-CT scan: Positron Emission Tomography - Computed Tomography,

UCMSC: umblical cord derived mesenchymal stem cells

CBMNC: Human cord blood mononuclear cells.
CARS : Childhood autism rating scale

ISAA: Indian scale for assessment of severity of autism.

CGI:Clinical global impression scale to assess severity of autism 
Table 1-2: Results of autism.

\begin{tabular}{|c|c|c|c|c|c|}
\hline Authors & Subjects & Type of cells & Dose of stem cells & $\begin{array}{l}\text { Mode of } \\
\text { transmission }\end{array}$ & Results of therapy \\
\hline Bradstreet et al. $(2014)^{(7)}$ & $\begin{array}{l}45 \text { patients with } \\
\text { autism } \\
\text { Age:3-15 y }\end{array}$ & Fetal stem cells & $\begin{array}{l}2 \text { infusions: } \\
1^{\text {st }} \text { day: } \\
1.6 \mathrm{ml} \\
\text { cell } / \mathrm{ml} . \\
2^{\text {nd }} \text { day: } \\
2.12 \mathrm{ml} \quad\left(30 \times 10^{6}\right) \\
\text { cell } / \mathrm{ml}\end{array}$ & $\begin{array}{l}1^{\text {st }}: \text { Intravenous } \\
2^{\text {nd: }} \\
\text { Subcutaneous }\end{array}$ & $\begin{array}{l}\text { 1-Improvement in ATEC score, } \\
\text { ABC specially language, } \\
\text { sensation. } \\
\text { 2-Improve cognition and behavior } \\
\text { 3-78\%patients show improved } \\
\text { eye contact, appetite. } \\
\text { 4-Improve immunity: }\end{array}$ \\
\hline Segal et al. $(2015)^{(8)}$ & $\begin{array}{l}22 \text { mice divided into } 2 \\
\text { groups: } \\
\text { a- MSC group } \\
\text { b- control group. }\end{array}$ & $\begin{array}{l}\text { Mesenchymal } \\
\text { stem cells } \\
(\mathrm{MSC})\end{array}$ & $\begin{array}{l}6 \mathrm{ml}(1 \mathrm{ml} / \text { injection } \\
\text { site) At conc: } \\
50,000 \mathrm{MSC} / \mathrm{mL} \\
\end{array}$ & $\begin{array}{l}\text { Into lateral } \\
\text { ventricles } \\
\text { bilaterally. }\end{array}$ & $\begin{array}{l}\text { MSC cause: } \\
\text { 1- Decrease repetitive behaviors } \\
\text { 2-Improve cognition rigidity. } \\
\text { 3- Elevated BDNF levels } \\
\text { 4- Increased hippocampal } \\
\text { neurogenesis } \\
\text {-But, No Differences in Anxiety- } \\
\text { Related Behaviors and } \\
\text { Locomotion }\end{array}$ \\
\hline
\end{tabular}

ATEC: Autism Treatment Evaluation Checklist

ABC: Aberrant Behavior Checklist

MSC: Mesenchymal stem cells,

BDNF: Brain deived neurotrophic factor. 
Table 1-3: Results of autism.

\begin{tabular}{|c|c|c|c|c|c|}
\hline Authors & Subjects & Type of cells & $\begin{array}{c}\text { Dose of stem } \\
\text { cells }\end{array}$ & $\begin{array}{c}\text { Mode of } \\
\text { transmission }\end{array}$ & Results of therapy \\
\hline Ha et al. $(2016)^{(9)}$ & $\begin{array}{l}33 \text { mice: } \\
\text { Divided into } \\
\text { a-Group } \\
\text { taking ASC } \\
\text { b-Group } \\
\text { taking saline }\end{array}$ & $\begin{array}{l}\text { Human } \\
\text { Adipose } \\
\text { derived stem } \\
\text { cell (hASC) }\end{array}$ & $\begin{array}{l}2 \mathrm{ml} \text { of } \mathrm{hASC} \\
\text { suspension } \\
\left(5 \times 10^{4} \text { cell/ml) }\right. \\
\text { early after } \\
\text { VPA-injection } \\
\text { (substance } \\
\text { induce autism) }\end{array}$ & $\begin{array}{l}\text { Into the third } \\
\text { ventricle }\end{array}$ & $\begin{array}{l}\text { 1-hASC reduce the repetitive } \\
\text { behaviors. } \\
\text { 2-h ASC improve the affected } \\
\text { sociality } \\
\text { 3-hASC decrease anxiety. } \\
\text { 4- hASC increase VEGF and IL-10 }\end{array}$ \\
\hline Perets et al. $(2017)^{(10)}$ & $\begin{array}{l}31 \text { mice into } \\
3 \text { groups: } \\
\text { a-Control }: 10 \\
\text { b- MSC: } 11 \\
\text { c-Nurown :10 }\end{array}$ & $\begin{array}{l}\text { Mesenchymal } \\
\text { stem } \\
\text { cells(MSC) and } \\
\text { neurotrophic } \\
\text { factors secreted } \\
\text { from MSC } \\
\text { (Nur own) }\end{array}$ & $\begin{array}{l}6 \mathrm{ml} \text { at } \\
\text { concentration } \\
(50.000 \text { cells } / \mathrm{ml} \\
)\end{array}$ & $\begin{array}{l}\text { Into the } \\
\text { cerebral } \\
\text { lateral } \\
\text { ventricle } \\
\text { bilaterally }\end{array}$ & $\begin{array}{l}\text { 1-MSC and NurOwn improve social } \\
\text { behavior in mice and increase } \\
\text { neurogenesis. } \\
\text { 2- MSC and NurOwn decrease the } \\
\text { repetieive behavior ,but NurOwn } \\
\text { effect continue for } 6 \text { months. } \\
\text { 3-NurOwn only decrease cognitive } \\
\text { rigidity. } \\
\text { So,both are effective but NurOwn } \\
\text { group is better. }\end{array}$ \\
\hline
\end{tabular}

hASC: Human adipose derived stem cell.

Nur own: Neurotrophic factor from mesenchymal stem cells.
VEGF: vascular endothelial growth factor.

IL-10: interleukin -10. 
Table 2-1: Results of Vocal fold regeneration

\begin{tabular}{|c|c|c|c|c|c|}
\hline Authors & Subjects & $\begin{array}{c}\text { Type of } \\
\text { stem cells }\end{array}$ & $\begin{array}{l}\text { Method of } \\
\text { injection }\end{array}$ & $\begin{array}{l}\text { Dose of stem } \\
\text { cells }\end{array}$ & Results \\
\hline $\begin{array}{l}\text { Hertegard et al. } \\
(2006)^{(11)}\end{array}$ & $\begin{array}{l}20 \text { Rabbit vocal folds } \\
\text { divided into } 2 \text { groups: } \\
\text { a- } 12 \text { vocal folds with scar } \\
\text { injected by saline or stem } \\
\text { cells } \\
\text { b- } 8 \text { normal vocal folds }\end{array}$ & $\begin{array}{l}\text { Mesenchymal } \\
\text { stem cells }\end{array}$ & $\begin{array}{l}\text { In lamina } \\
\text { propria of vocal } \\
\text { folds or in } \\
\text { superficial part } \\
\text { of thyro- } \\
\text { arytenoid } \\
\text { muscle }\end{array}$ & $\begin{array}{l}80.000 \text { cell in } \\
\text { each vocal fold }\end{array}$ & $\begin{array}{l}\text { 1-Better Viscoelasticity in treated group } \\
\text { 2- better healing } \\
\text { 3- less collagen deposition } \\
\text { Stem cell continue for long time after } \\
\text { injection. } \\
\text { 4-Stem cells persisted for } 4 \mathrm{w}\end{array}$ \\
\hline Svensson et al. $(2010)^{(12)}$ & $\begin{array}{l}22 \text { vocal folds of rabbits } \\
\text { divided into } 3 \text { groups: } \\
\text { a- } 10 \text { scarred vocal folds } \\
\text { injected by stem cells. } \\
\text { b- } 8 \text { scarred vocal folds } \\
\text { injected by saline only. } \\
\text { c- } 4 \text { vocal folds without } \\
\text { scar as control group }\end{array}$ & $\begin{array}{l}\text { Human } \\
\text { Mesenchymal } \\
\text { Stem cells }\end{array}$ & $\begin{array}{l}\text { In lamina } \\
\text { propria of vocal } \\
\text { folds or in } \\
\text { superficial part } \\
\text { of thyro- } \\
\text { arytenoid } \\
\text { muscle }\end{array}$ & $\begin{array}{l}80.000 \text { to } \\
100.000 \text { cell in } \\
\text { each vocal fold }\end{array}$ & $\begin{array}{l}\text { 1-Increased elasticity in stem cell } \\
\text { injected vocal folds than untreated } \\
\text { vocal folds. } \\
\text { 2-Decrease thickness of lamina } \\
\text { propria and decreases collagen } \\
\text { percentage. } \\
\text { 3-Stem cells didnot persist for } 3 \mathrm{~m}\end{array}$ \\
\hline Hong et al. $(2011)^{(13)}$ & $\begin{array}{l}12 \text { rabbits with } 24 \text { scarred } \\
\text { vocal folds divided into } 2 \\
\text { groups: a- } 12 \text { vocal folds } \\
\text { injected by phosphate } \\
\text { buffered saline b- } 12 \text { vocal } \\
\text { folds injected by Human } \\
\text { adipose derived stem cell }\end{array}$ & $\begin{array}{l}\text { Human } \\
\text { adipose } \\
\text { derived stem } \\
\text { cell }\end{array}$ & In the vocal fold & Not available & $\begin{array}{l}\text { Human adipose derived stem cell group } \\
\text { lead to: } \\
\text { 1- Good healing of vocal fold } \\
\text { 2- Decreased scar formation } \\
\text { 3- less fibrosis and granulation } \\
\text { 4- less inflammation } \\
\text { 5-Stem cells persisted for } 12 \mathrm{w} \text {. }\end{array}$ \\
\hline Peng et al. $(2013)^{(14)}$ & $\begin{array}{l}9 \text { canines have } 18 \text { vocal } \\
\text { folds with wounds divided } \\
\text { into } 2 \text { groups: } \\
\text { a- } 9 \text { left vocal folds injected } \\
\text { by laryngeal mucosa } \\
\text { mesenchymal stem cells } \\
\text { with collagen. b- } 9 \text { Right. } \\
\text { vocal folds injected by } \\
\text { collagen }\end{array}$ & $\begin{array}{l}\text { laryngeal } \\
\text { mucosa } \\
\text { mesenchymal } \\
\text { stem cells }\end{array}$ & $\begin{array}{l}\text { In the vocal } \\
\text { folds near the } \\
\text { site of scar }\end{array}$ & $2 \times 10^{6}$ cells & $\begin{array}{l}\text { 1-Stem cell group: } \\
\text {-less atrophy } \\
\text {-less granulation tissue } \\
\text {-less collagen } \\
\text {-more regular surface } \\
\text {-more elasticity } \\
\text { 2-Cells are found until 8w in lamina } \\
\text { propria }\end{array}$ \\
\hline
\end{tabular}


Table 2-2: Results of Vocal fold regeneration

\begin{tabular}{|c|c|c|c|c|c|}
\hline Authors & Subjects & $\begin{array}{l}\text { Type of stem } \\
\text { cells }\end{array}$ & $\begin{array}{l}\text { Method of } \\
\text { transmission }\end{array}$ & $\begin{array}{c}\text { Dose of } \\
\text { stem cells }\end{array}$ & Results \\
\hline Mo Kim et al. (2014) & $\begin{array}{l}40 \text { Rabbit vocal folds divided into: } \\
\text { a- Normal VF. } \\
\text { b- Injured VF injected by phosphate } \\
\text { buffered saline. } \\
\text { c- Injured VF injected by HA/ALG } \\
\text { hydrogel. } \\
\text { d- Injured VF injected by MSCs } \\
\text { e- Injured VF injected by MSCs in } \\
\text { HA/ALG hydrogel. } \\
\text { (Each group is } 8 \text { vocal folds) }\end{array}$ & $\begin{array}{l}\text { Mesenchymal } \\
\text { stem cells }\end{array}$ & $\begin{array}{l}\text { In site of injury } \\
\text { of vocal folds }\end{array}$ & $\begin{array}{l}1 \times 10^{6} \\
\mathrm{hAdMSCs} \\
\text { in } 50 \mathrm{ml} \text { of } \\
\text { saline or } 50 \\
\text { ml of HA/ } \\
\text { ALG } \\
\text { hydrogel }\end{array}$ & $\begin{array}{l}\text { 1- MSCs in HA/ALG hydrogel } \\
\text { injection has better results than } \\
\text { MSCs only } \\
\text { (more elasticity -less collagen- } \\
\text { more growth factors) } \\
2 \text {-stem cells survived for } 1 \text { months }\end{array}$ \\
\hline Hu et al. $(2014)^{(16)}$ & $\begin{array}{l}30 \text { canine of acute vocal fold wound } \\
\text { divided into } 3 \text { groups: } \\
\text { a- } 10 \text { vocal folds injected by mesenchymal } \\
\text { stem cell } \\
\text { b- } 10 \text { vocal folds injected by fibroblasts } \\
\text { derived from stem cells. } \\
\text { c- Control normal group ( } 10 \text { vocal folds). }\end{array}$ & $\begin{array}{l}\text { Mesenchymal } \\
\text { stem cells }\end{array}$ & $\begin{array}{l}\text { At the site of } \\
\text { injury of vocal } \\
\text { fold }\end{array}$ & $1 \times 10^{5}$ cells & $\begin{array}{l}\text { 1-Smooth edge of vocal fold in } \\
\text { stem cell group. } \\
\text { 2-Elastin increased in group (b). } \\
\text { 3-Collagen decrease in group(a-b) } \\
\text { 4-Hyaluronic acid, fibronectin are } \\
\text { similar between injected groups }\end{array}$ \\
\hline Valerie et al. $(2015)^{(17)}$ & $\begin{array}{l}74 \text { rabbits divided into } 3 \text { groups: } \\
\text { a- } 8 \text { control group } \\
\text { b- } 15 \text { chronic scarred vocal folds injected } \\
\text { by Hyaluronic acid. } \\
\text { c- } 15 \text { chronic scarred vocal folds injected by } \\
\text { Stem cell }\end{array}$ & $\begin{array}{l}\text { Autologous } \\
\text { adipose derived } \\
\text { stem cells }\end{array}$ & $\begin{array}{l}\text { In the middle } \\
1 \backslash 3 \text { of the vocal } \\
\text { fold after } 18 \mathrm{~m} \\
\text { of scar } \\
\text { formation }\end{array}$ & 10.000 cells & $\begin{array}{l}\text { 1- Thickness of lamina propria } \\
\text { decreased in stem cell group. } \\
\text { 2-Good healing in stem cell group. } \\
\text { 3-Increased elasticity of vocal fold } \\
\text { in stem cell group. } \\
\text { 4-Decreased collagen in stem cell } \\
\text { group }\end{array}$ \\
\hline
\end{tabular}

VF: Vocal Folds

HA/ALG: hyaluronic acid/mildly cross linked alginate hydrogel.

MSCs: Msenchymal stem cells. 


\section{Results of autism}

There are 6 studies about the role of stem cells in treatment of autism. According to the subjects, 3 studies used autistic patients and the other three used mice injected by certain materials to be autistic like. According to the type of the study, 2 studies were randomized. Blinding occurred only in one study. 4 studies used control groups, but the remaining 2 studies did not use control group.

According to the type of stem cells, one study used mesenchymal stem cells, one study used mononuclear stem cells, one study used fetal stem cells, one study used adipose derived stem cells, one used combination between mesenchymal and mononuclear stem cells and the last one used mesenchymal stem cells and neurotrophic factors secreated from mesenchymal stem cells.

The dose of stem cells was different between the 6 studies. 4 studies used single doses, but 2 studies used multiple injections. The mode of administrationwas different between the studies. It varied between intrathecal, intravenous, subcutaneous, into third ventricle and in the lateral ventricle.

Most of the studies measured repetitive behaviors, sociality, general behavior, percentage of growth factors and cognition level. Most of the studies showed improvement in different scales of autism. One study that did not show improvement in anxiety behaviors, but showed improvement in other parameters. Another one study showed no improvement in language. The results showed better improvement in combination groups where the subjects took two types of stem cells more than who took one type of stem cells.

According to the safety of stem cell injection in the autism, two studies measured the side effects after therapy. One study detected no side effects; the other detected few side effects as nausea, vomiting, back pain that disappeared after treatment.

\section{Results of vocal fold regeneration}

In this study, we reached to 7 studies that used stem cells in vocal fold regeneration after atrophy and scar. Two of these studies were randomized .The other five studies were non randomized. All of the studies were carried on animals.

Injection of stem cells was carried out in the injury site, in the lamina propria or in the superficial layer of thyro-arytenoid muscle. Injection in different sites did not differ in the results. The studies used different doses of stem cells for regeneration of vocal fold injury.

Five studies used mesenchymal stem cells and two studies used adipose derived stem cells .One of the studies that used mesenchymal stem cells, used fibroblasts in another group for a comparison between their effects. All types of stem cells produced improvement in histology, morphology and movement of vocal fold mucosa.

Stem cell injection in vocal folds has many advantages as it increased elasticity of vocal folds, decreased fibrosis and scar formation, decreased collagen deposition and decreased thickness of vocal fold especially, the lamina propria. All the previous factors lead to improvement of vocal fold function and decreased the scar formation after vocal fold injury.

\section{DISCUSSION}

\section{Stem cell therapy in autism:}

There were 6 studies talking about the role of stem cell in treatment of autism. A large aspect of heterogeneity was noticed between the parameters of study including subjects, type of stem cells, dose of stem cells and mode of administration. This heterogeneity makes it difficult to reach to the most effective dose, type of administration or the effective type of stem cells. More comparative studies that compare different types of stem cells, different doses and different mode of administration on the autistic children are needed. Among the six studies, three of them used animals as models of autism. The other three studies used autistic children. Using animals as models of autism did not provide information about language and communication abilities after therapy. In the future, more clinical studies that use autistic children as models are needed.

Risk of biases was present in most of studies as only two studies reported the randomization. Blinding occurred only in one study. More randomized and blinded studies are needed to reach to better results with fewer biases.

Most of the studies showed statistically significant improvement in different scales of autism as CARS (Childhood autism rating scale) ,ISAA(Indian scale of autism ) that measures the severity of autism and CGI(Clinical global impression scale) that measures also the severity of autism. There was also improvement in behavior.

Tao et al.(2013) compared between the effect of injection of one type of stem cells (human cord blood mononuclear cells) and combination of two types of stem cells (human cord blood mononuclear cells and umbilical cord mesenchymal stem cells). They found that the results were better in combination group. This means that injection of two types of stem cells gives better results. 
Using neurotrophic factors derived from stem cells produced better results than stem cells themselves. Perets et al. (2017) compared between the effect of mesenchymal stem cells and neurotrophic factors derived from them. They found that neurotrophic factors had more effect on decreasing repetitive behavior and increasing neurogenesis.

As regards language, the three studies that were done on autistic children monitored language after therapy. Tao et al.(2013) showed no statistical improvement in language after therapy. Sharma et al.(2013) noticed improvement in language in few children only. Ha et al. (2016) showed statistically significant improvement in language. Ha et al. (2016) used in their study fetal stem cells that have high proliferation capacity. This means that fetal stem cells may have higher effect on language than other types. There is a need for more studies using fetal stem cells on autistic children to confirm this result.

As regards the safety of stem cell injection in the autism, two studies measured the side effects after therapy. One study detected no side effects; the other detected few side effects disappeared after treatment, so stem cell injection is a safe procedure.

\section{Stem cell therapy in vocal fold regeneration}

There were 7 studies about the role of stem cell therapy in vocal fold scar and atrophy. Heterogeneity was noticed between certain parameters of study including dose of stem cells and site of administration. All of the doses are effective, but we did not know the best dose. So, each dose should be tried with control group to detect its efficacy and then comparing different doses to detect which is the best. Most of the authors injected stem cells in acute stage after scar formation. We had only one study investigating the effect of therapy on chronic scar. Valerie et al. (2015) used chronic scars in their study. The results were good (good healing-increase elastindecrease collagen).Further studies on chronic scar are needed to compare the effect of injection in acute versus chronic scar.

All of studies found that stem cell injection in vocal folds had many advantages as it increased elasticity of vocal folds, decreased fibrosis and scar formation, decreased collagen deposition and decreased thickness of vocal fold especially, the lamina propria. All the previous factors led to improved vocal fold function and decrease in the incidence of scar formation after vocal fold injury. Injection of stem cells in the vocal folds is an easy and rapid method that could be done in the outpatient clinic without general anesthesia.

These results might contain biases as only two studies were randomized. The other 5 studies were none randomized. We need more randomized studies with less risk of biases. Mesenchymal stem cells are used in $70 \%$ of studies. Adipose derived stem cells could persist in vocal fold tissue for longer time than other types.

Putting stem cells in certain media could improve its effect. Mo Kim et al. (2014) used mesenchymal stem cells in hyaluronic acid/mildly crossed linked alginate hydrogel. This led to better results (better elasticity-more growth factors).

$\mathrm{Hu}$ et al. (2014) compared between the effect of mesenchymal stem cells and fibroblasts on vocal fold scar. They found that both of them produced increase hyaluronic acid, increase fibronectin and decrease collagen, but fibroblasts produced more elastin level. So, using certain proteins derived from stem cells as fibroblasts could produce better results than stem cells.

All of the studies used animals as subjects. Authors depended on histology and morphology in assessment of improvement after therapy. The correlation between histology and voice quality is not straightforward. Studying of the histology and morphology gives us idea about the effect of stem cells on vocal fold structure, but the quality of voice could not be assessed. So, we need more studies that carried on humans to assess voice quality after therapy.

\section{CONCLUSION}

Stem cell therapy is considered as a new and good therapy for the future of medicine. Stem cell therapy can be done to solve some of the communication disorders as autism and regeneration of vocal folds after atrophy and scars. In autism, Stem cell therapy is effective in increasing attention, decreasing the repetitive movements with improvement in communication skills of autistic children with minimal side effects. In regeneration of vocal fold, stem cell therapy is effective in improving the histology and morphology of vocal folds. We need more studies on humans and comparing the effect of different doses to know the effective dose.

\section{REFERENCES}

(1) Tuch BE: Stem cells a clinical update. Australian Family Physician, (2006); 35 (9): 719-721. 
(2) Mascetti V L and Pedersen R A : Human-mouse chimerism validates human stem cell pluripotency. Cell Stem Cell, (2016); 18: 67-72.

(3) Subrammaniyan R, Amalorpavanathan J, Shankar R, Rajkumar M, Baskar $S$, Manjunath S, Senthilkumar R, Murugan P, Srinivasan $\mathbf{V}$ and Abraham S (2011): Application of autologous bone marrow mononuclear cells in six patients with advanced chronic critical limb ischemia as a result of diabetes: our experience. Cytotherapy, 13 (8): 993-999.

(4) Park D, Borlongan C, Willing A, Eve D, Cruz L, Sanberg C, Chung Y and Sanberg P: Human umbilical cord blood cell grafts for brain ischemia. Cell Transplant, (2009); 18 (9):985-998.

(5) Siniscalco D , Sapone A, Cirillo A, Giordano C, Maione S and Antonucci N: Autism spectrum disorders: is mesenchymal stem cell personalized therapy the future? Journal of Biomedicine and Biotechnology, (2012); 2012:1-6.

(6) Beyth S, Borovsky Z, Mevorach D, Liebergall $M$ and Gazit $Z$, Aslan H, Galun $\mathbf{E}$ and Rachmilewitz $\mathbf{J}$ : Human mesenchymal stem cells alter antigenpresenting cell maturation and induce T-cell unresponsiveness.Blood, (2005); 105: 22142219.

(7) Kim Y, Se H, Choi J, Lee S, Jeong C, Lee J, Lim J: Adipose-derived stem cell containing hyaluronic acid/ alginate hydrogel improves vocal fold wound healing. Laryngoscope, (2014); 124:64-72.

(8) Ohno T, Hirano S, Kanemaru S, Yamashita M, Umeda $H$, Suehiro A, Nakamura $\mathbf{T}$ and Ito $\mathbf{J}$ : Expression of extracellular matrix proteins in the vocal folds and bone marrow derived stromal cells of rats. Eur Arch Otorhinolaryngol , (2008); 265:669-774.

(9) Yoshida A , Kitajiri S, Nakagawa T, Hashido $\mathbf{K}$, Inaoka $\mathbf{T}$ and Ito $\mathbf{J}$ : Adipose tissue-derived stromal cells protect hair cells from aminoglycoside laryngoscope, (2011); 121(6):1281-1286.
(10) Imaizumi M, Nomooto $Y$, Sugino T, Miyake M, Wada I, Naakamura T, Omori K : Potential of induced pluripotent stem cells for the regeneration of the tracheal wall. Ann Otol Rhinol Laryngol., (2010); 119(10):697703.

(11) Sharma A, Gokulchandran N, Sane H, Nagrajan A,Paranjape A, Kulkarni P,Shetty A,Mishra P,Kali M, Biju $H$ and Badhe $\mathbf{P}$ : Autologous Bone Marrow Mononuclear Cell Therapy for Autism: An Open Label Proof of Concept Study. Stem Cells International, (2013); 623875-623887.

(12) Tao Y, Zhang Y, Liu M, Qiuwaxi J, Ashwood P, Cho S, Huan Y, Cun Ge R,Chen $X$,Wang $Z$, Kim B and Hu $X$ : Transplantation of human cord blood mononuclear cells and umbilical cord-derived mesenchymal stem cells in autism. Translational Medicine, (2013); 11:196-208.

(13) Bradstreet J, Sych N, Antonucci N, Klunnik M, Ivankova O, Matyashchuk I, Demchuk M and Siniscalco D : Efficacy of Fetal Stem Cell Transplantation in Autism Spectrum Disorders: An Open-Labeled Pilot Study. Stem Cells International, (2014); 23(1):105-112.

(14) Segal-Gavish H, Karvat G, Barak N, Barzilay R, Ganz J, Edry L, Aharony I, Offen D, and Kimchi $\mathbf{T}$ :Mesenchymal Stem Cell Transplantation Promotes Neurogenesis and Ameliorates Autism Related Behaviors in BTBR Mice. Autism Research, (2015); 9: 17-32.

(15) Ha S,Park H,Mahmood U,Ra J , Suh $\mathbf{Y}$ and Chang K: Human adipose-derived stem cells ameliorate repetitive behavior, social deficit and anxiety in a VPA-induced autism mouse model. Behav Brain Res, (2016); 15 (317):479-484.

(16) Perrets N, Segal-Gavish H, Gothelf Y, Barzilay R,Yael Barhum Y, Abramov N, Hertz S, Morozov D, London M, Offen D : Long term beneficial effect of neurotrophic factors-secreting mesenchymal stem cells transplantation in the BTBR mouse model of autism. Behavioral brain research, (2017); 331: 254-260.

(17) Hertegrad S , Cedervall J , Svensson B , Forsberg K, Maurer F, Vidovska D, Olivius P, Ahrlund- Richter L, Le Blanc K 
: Viscoelastic and histologic properties in scarred rabbit vocal folds after mesenchymal stem cell injection. Laryngoscope, (2006); 116:1248-1254.

(18) Svensson B, Nagubothu S, Cedervall J, Le Blanc K, Ahrlund-Richter L, Tolf A, Hertegard $\mathbf{S}$ : Injection of human mesenchymal stem cells improves healing of scarred vocal folds: Analysis using a xenograft model. The laryngoscope, (2010); 120: 1370-1375.

(19) Hong SJ, Lee SH, Jin SM, Kwon SY, Jung KY, Kim MK, Park $H$ and Lee KW :Vocal fold wound healing after injection of human adipose-derived stem cells in a rabbit model. Acta Oto-Laryngologica , (2011); 131: 1198-1204.

(20) Peng H, Ming L, Yang R, Liu Y, Liang Y, Zhao $Y$, Jin $Y$ and Deng $Z$ : The use of laryngeal mucosa mesenchymal stem cells for the repair the vocal fold injury . Biomaterials, (2013); 34: 9026-9035.

(21)Mo Kim Y,Choi J,Lee S,Ra J,Lee J,Lim J :Adipose -Derived stem cell containing hyaluronic acid /alginatehydrogel improve vocal fold wound healing .The Laryngoscope, (2014); 124:64-72.

(22) Hu R, Ling W, Xu1 W and Han D : Fibroblast-Like Cells Differentiated from Adipose-Derived Mesenchymal Stem Cells for Vocal Fold Wound Healing. PLOS ONE, (2014); 9 (3):92676-92684.

(23) Valerie A, Vassiliki K, Irini M, Nikolaos P, Karampela $\mathbf{E}$ and Apostolos P. : Adipose-Derived Mesenchymal Stem Cells in the Regeneration of Vocal Folds: A Study on a Chronic Vocal Fold Scar. Stem Cells International, (2015); 90102799010290 . 


\section{لعلاج بالخلايا الجذعية فى أمراض التخاطب

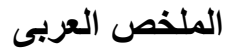

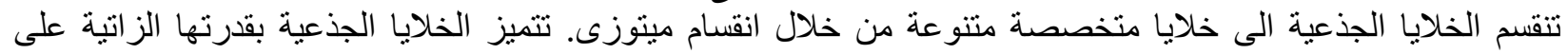

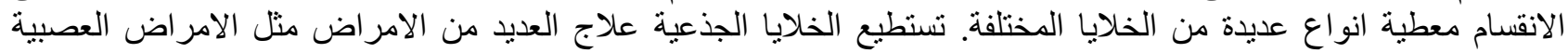

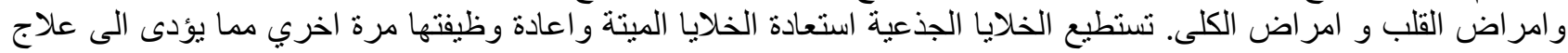

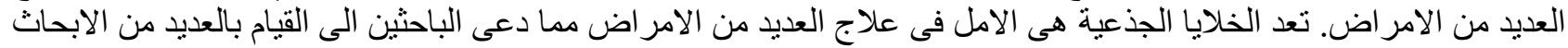

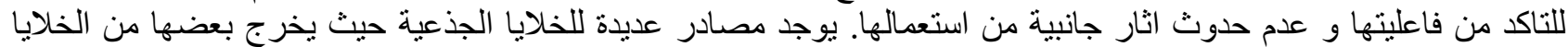

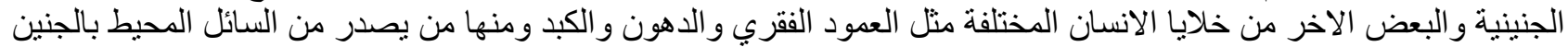

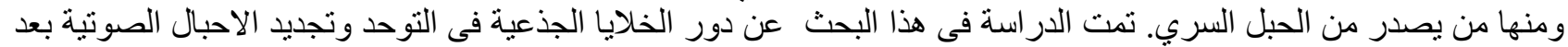

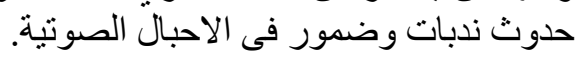

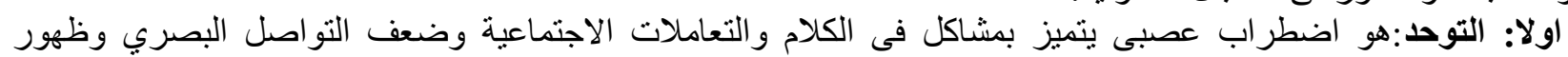

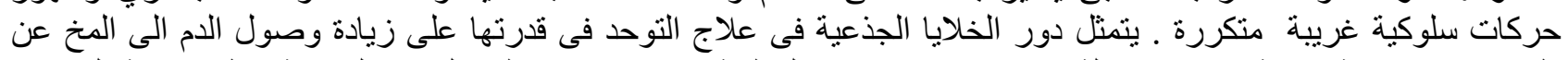

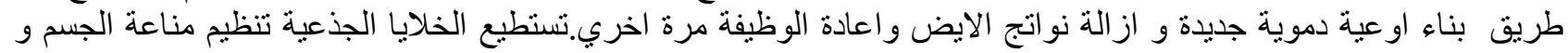

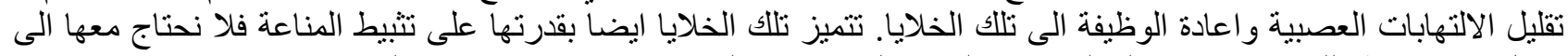

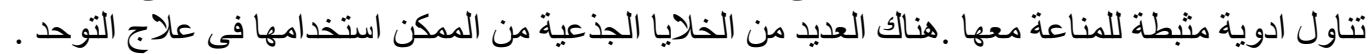

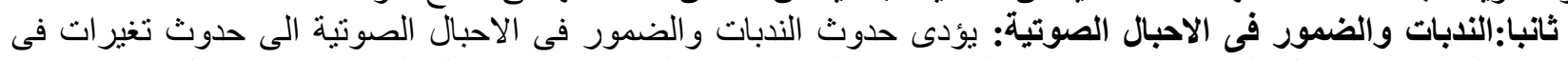

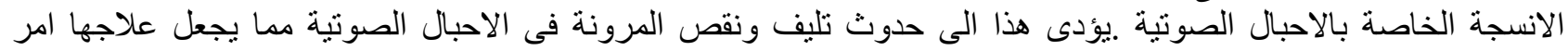

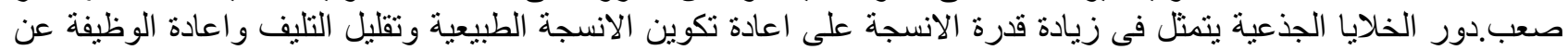

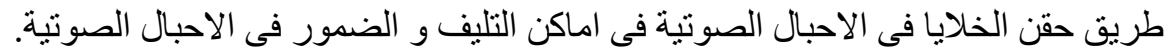

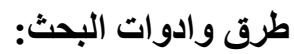
معايير ادراج الابحاث: كل البحث: الابحاث التى تتحدث عن دور الخلايا الجذعية فى علاج امراض التخاطب كمرض التوحد و

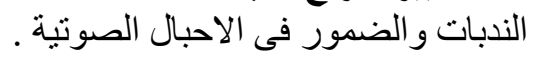

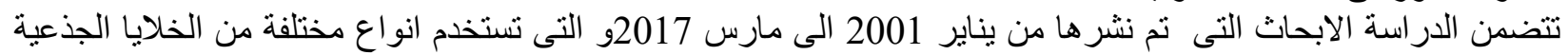

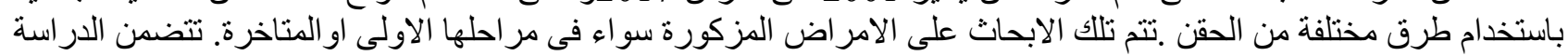

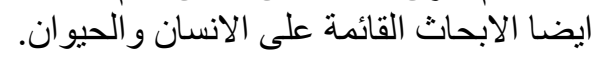

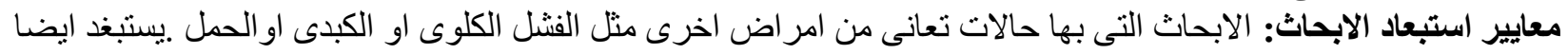

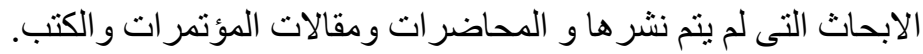
مصدر المعلومات: من الابحاث منذ 2001 التى مارس 2017من مو اقع عمية مختلفة باستخدام محركات بحث مختلفة.

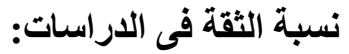

تمت قياس نسبة التقة في الابحاث التهاث التى تم استعمالها فى الدر اسة. نتائج البحث:

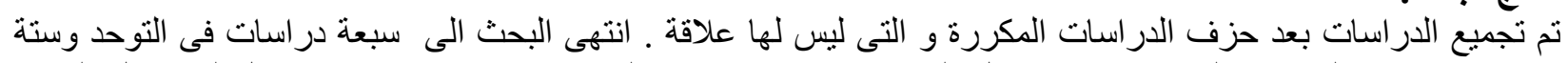

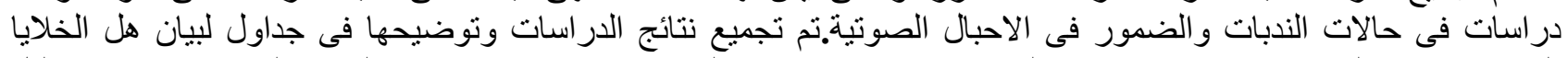

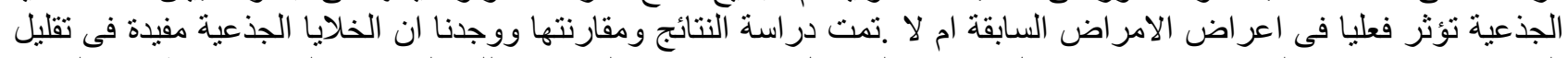

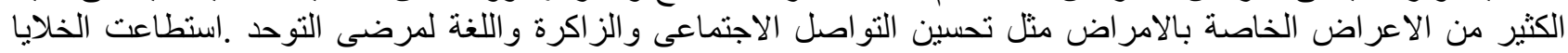

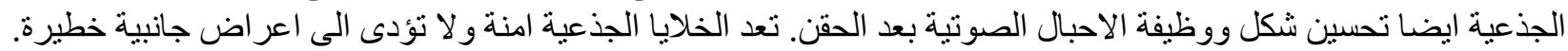

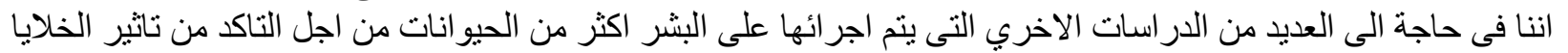

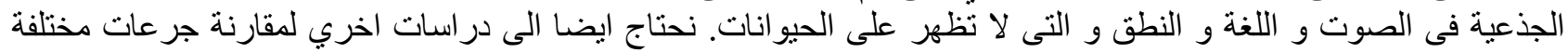

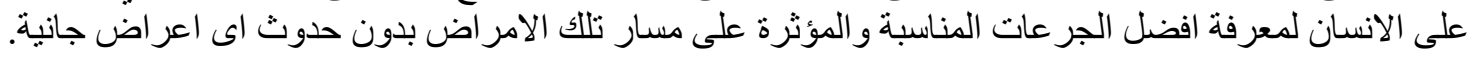

